\title{
Corporate governance and cross-listing: evidence from European companies
}

\author{
Revised: 3 May 2005 \\ *Dariusz Wójcik, +Gordon L Clark, and \#Rob Bauer
}

\begin{abstract}
This paper documents the relationship between cross-listing and corporate governance of the largest European companies between 2000 and 2003. Companies with a U.S. cross-listing, and particularly those listed on a U.S. stock exchange had higher corporate governance ratings than companies without a U.S. cross-listing. Corporate governance advantage of the U.S. cross-listed firms holds if we control for the country of origin and other company characteristics, and it was more consistent in 2003 than in 2000, suggesting a possible impact of the Sarbanes-Oxley Act. The U.S. cross-listed firms had higher ratings not only in terms of disclosure but also in terms of board structure and functioning. In contrast, they had no advantage in terms of shareholders' rights and duties. The advantage of U.S. cross-listed firms can be traced back to at least a couple of years before the time of cross-listing, which leaves the question whether their superior corporate governance is the effect of U.S. cross-listing open. In contrast to the importance of cross-listing in the U.S., there is no significant relationship between corporate governance and cross-listing within Europe. Implications are drawn for the debate on bonding and the future of European stock markets.
\end{abstract}

Keywords: corporate governance, cross-listing, bonding, Europe

JEL classifications: G15, G34, K00, P51

\section{Acknowledgements}

Jean-Nicolas Caprasse and Kristof Ho Tiu, Deminor Rating SA, have provided data and invaluable guidance on corporate governance ratings. Shervin Setareh, Deminor Rating SA offered insightful comments on cross-listings and corporate governance. I would like to thank the following people and stock exchanges for help with collecting data on European cross-listings: Michelle Egede Paustian (Copenhagen), Ulf Person (Stockholm), Amelia Sanchez (Madrid), Line Mauseth (Oslo), Pim Harte (Amsterdam), and Silvia Preszl (Vienna). We are grateful for the comments of the participants of the European Corporate Governance Symposium, organised by the European Financial Management Association and Leeds University Business School in Leeds, 28-30 April 2005, as well as the participants of the European Science Foundation Exploratory Workshop on Economic Geography and European Finance held at Jesus College, Oxford, 16-19 September 2004. We have obtained invaluable feedback from Andrew Karolyi, Marc Deloof, and Jordan Siegel. None of the above is responsible for any mistakes or omissions.

*Jesus College, Oxford OX1 3DW, UK < dariusz.wojcik@ jesus.ox.ac.uk> +School of Geography \& the Environment and Said Business School; Mansfield Rd, Oxford OX1 3TB, UK

\#Department of Finance, Maastricht University and ABP Investments, P.O. Box 2889

6401 DJ Heerlen, Oude Lindestraat 706411 EJ Heerlen, The Netherlands 


\section{Introduction}

The listing of corporate stock on foreign exchanges and trading stocks in foreign markets have been one of the most fascinating aspects of financial globalisation in the last two decades. In late 1990s there were over 4,000 foreign listings in the world. Since then however, their number has been decreasing at a considerable rate (Karolyi 2004). In addition, we have witnessed a major reversal in the geography of cross-listings. While until late 1980s European exchanges were the main destination of both intraEuropean and intercontinental cross-listing, since then the major cross-listing flows followed the route from Europe to the U.S. markets (Pagano et al. 2002). In the same period of time we have witnessed a heated debate on corporate governance. Spurred by a number of factors including the revealed deficiencies of the Asian, Russian and Brazilian crisis-stricken economies, the world-wide privatisation wave, the rise of funded pensions and institutional investors, and recent scandals in the U.S. and Europe (Becht et al. 2003) corporate governance is now on the top of the economic policy agenda with Sarbanes Oxley Act in the US, the Lisbon Strategy in the EU (EC 2003), corporate governance reform in Japan (Gilson and Milhaupt 2004), and involvement of international organisations (OECD 1999).

With cross-listings and corporate governance being hot topics, it is not surprising that the intersection between them also attracts a lot of interest. In simple terms, foreign listing represents a contact between corporate governance of the listing company's home and host environments. One general question is how much diffusion is taking place between the two and to what extent the company adjusts to the host environment. Another debated issue is whether the relationship between the home and the host corporate governance environment is important for the decision whether and where to cross-list. According to Licht (2004), companies avoid exchanges with strict corporate governance requirements, and in order to attract foreign listings stock exchanges and regulators are lax applying their domestic standards to foreign companies. In contrast, the proponents of the so-called bonding hypothesis claim that firms can "opt into governance systems, disclosure standards, and accounting rules that may be more rigorous than those required or prevailing in their jurisdiction of incorporation" (Coffee 1999, 651). These firms would be motivated mainly by the gains of the increased credibility in the eyes of small shareholders, and ultimately higher stock market valuation and lower cost of capital. If cross-listing was indeed linked with stricter corporate governance, the lack of cross-listing could arise suspicion of investors, putting companies listed only domestically under pressure to adjust their corporate governance as well (Stulz 1999). Thus, at stake in the debate on the relationship between crosslistings and corporate governance is not only the future of stock exchanges, the extraterritorial reach of stock market regulators, and corporate governance of crosslisting companies. At stake is also the potential contribution of cross-listings to convergence in corporate governance and the future of capital market integration.

There are two groups of recent empirical research supporting the bonding theory. The first group has focused on stock market implications of foreign listings, suggesting that non-U.S. companies that cross-list in the U.S. achieve higher valuations, offer lower private benefits of control to their controlling shareholders and managers, and enjoy better access to capital than companies without a cross-listing in the U.S. (Miller 1999; Reese and Weisbach 2002; Doidge 2004; Doidge, Karolyi, Stulz 2004). It is on the basis of the stock market phenomena that coincide with a cross-listing that the authors infer a positive impact of U.S. cross-listings on corporate governance of foreign companies. The second group of research attempts to explore the relationship between corporate governance and cross-listing directly. Klapper and Love (2003) as well as Durnev and 
Kim (2005) show that within emerging markets firms listing on a US stock exchange tend to have higher corporate governance ratings. Doidge, Karolyi, and Stulz (2004b) further corroborate these findings claiming that a US cross-listing as a form of access to global capital markets increases firm-level incentives for good corporate governance.

The objective of our paper is to contribute to the understanding of the relationship between corporate governance and cross-listing with a dynamic study focusing on European firms. Through access to proprietary data on corporate governance in the largest European corporations, constituents of the FTSE Eurotop 300 index in the period between 2000 and 2003, provided by Deminor Rating S.A., combined with data on the cross-listing status of European companies, covering both U.S. listings as well as crosslistings within Europe, we are able to address the following major research questions:

1. How does corporate governance of U.S.-cross-listed European companies compare to corporate governance of companies from the same country that do not cross-list in the U.S.?

2. What is the relationship between the type of U.S. cross-listing and corporate governance?

3. What is the relationship between cross-listing within Europe and corporate governance?

We will argue that companies with a U.S. cross-listing, and particularly those listed on a U.S. stock exchange commanded higher corporate governance ratings than companies without a U.S. cross-listing. Corporate governance advantage of the U.S. cross-listed firms holds if we control for the country of origin and other company characteristics, and it was stronger in 2003 than in 2000. Regarding the structure of corporate governance, the U.S. cross-listed firms had systematically higher ratings not only in terms of disclosure but also in terms of board structure and functioning. In contrast, they had no advantage over non-U.S. cross-listed firms in terms of shareholders' rights and duties. The U.S. cross-listed companies have superior corporate governance at least a couple of years before the time of cross-listing, which leaves the question whether their superior corporate governance is the effect of U.S. cross-listing open. In contrast to the importance of cross-listing in the U.S., there is no significant relationship between corporate governance and cross-listing within Europe.

The rest of the paper is organised as follows. The next section will draw a conceptual framework linking corporate governance and cross-listings, leading to the hypotheses presented in section three. Section four describes data sources, methodology and sample. Section five analyses the bivariate relationship between corporate governance and the U.S. cross-listing status in four major European countries. Section six extends the bivariate analysis to the whole sample, accounting for corporate governance before and after cross-listing. Section seven presents a multivariate analysis of the relationship between corporate governance and the U.S. cross-listing status, in which we control for a number of factors that are likely to affect cross-listing. Section eight explores the relationship between corporate governance and cross-listings within Europe. Section nine concludes.

\section{Corporate governance and cross-listing}

Corporate governance is concerned with the ways in which suppliers of finance to corporations assure themselves a return on their investment. At the heart of corporate governance lies the risk that corporate managers will misuse or even steal the capital entrusted to corporations (Shleifer and Vishny 1997). Minority shareholders who could be abused not only by managers but also by controlling shareholders face this risk in its most acute form. It is managers and controlling shareholders who can enjoy the so- 
called private benefits of control at the expense of minority shareholders. Benos and Weisbach (2004) classify them into non-pecuniary and pecuniary benefits. Nonpecuniary benefits include the "ability to direct company's resources to a cause one agrees with, a preference for glamorous projects, or the use of a position for the enhancement of one's human capital" (Ibid, 3). More substantially "private benefits can have enormous direct financial effect on minority shareholders, through transactions that divert corporate resources to other companies owned by the managers or their families" (Ibid). In this section we will apply the notion of private benefits of control as the starting point for building a conceptual framework of the relationship between corporate governance at company level and cross-listing.

First, we need to recognise that private benefits of control are by definition the enemy of a minority shareholder oriented model of corporate governance. By discouraging minority shareholdings, private benefits restrict a firm's access to external capital, and particularly equity capital. This claim has been supported with empirical studies, with La Porta et al. (1997) finding a significant positive relationship between the strength of minority shareholders' legal rights in a country and the ability of firms in this country to raise capital. At an individual company level, the positive (negative) relationship between minority shareholder oriented corporate governance (the level of private benefits of control) and stock market valuation has been detected in the U.S. (Gompers et al. 2003), Asia (Claessens et al. 2002), and Europe (Bauer et al. 2004). Restricted access to external finance implies that company cannot realise some positive net present value investment projects. It is the trade-off between private benefits and access to external finance that presents a manager and/or a controlling shareholder with a dilemma. "The private benefits he enjoys prevent him from accessing capital market, and hence from reaping the positive net present value of the project. If he could somehow commit to forgo taking private benefits personally (and convince potential investors of his commitment), he could then undertake the project and reap his share of the net present value. By this logic, if the project were sufficiently valuable, then it would make sense for managers to 'bond' themselves to avoid taking private benefits" (Benos and Weisbach 2004, 12-13).

If the benefits of enhanced access to external finance outweigh the forgone private benefits in the calculation of the managers and/or controlling shareholders ${ }^{1}$, the question is how they make their promise to forgo private benefits credible in the eyes of potential investors. In this context, Jeffrey Gordon (1988) wrote about U.S. companies listing on the New York Stock Exchange (NYSE), and this way obliging themselves not to recapitalize with dual class common stock. In other words the U.S. companies were bonding their promise to maintain a one share one vote capital structure, crucial for the protection of minority shareholders. However, if a solution to a firm with bonding desire is not available at home, a company can make a promise of lower private benefits and more minority shareholder friendly governance by listing their shares abroad. Coffee (1999) and Stulz (1999) were the first to propose bonding as a reason for foreign firms to list on U.S. stock exchanges. Of course, beyond the costs of forgone private benefits of control there are also direct costs of cross-listing such as listing fee. Importantly, some direct costs are related to corporate governance. For example, an exchange may require increased disclosure on corporate governance or the participation of independent directors on the board of the company applying for cross-listing.

\footnotetext{
${ }^{1}$ For the sake of simplicity we do not account for differences of interest between managers and controlling shareholders.
} 
To appreciate the bonding mechanism we need to distinguish between legal bonding and reputational bonding. Legal bonding involves the rules set by stock exchange and capital market regulators that a cross-listing company has to abide. The source of reputational bonding is investment community and industry at large, including investors, investment banks, rating agencies, investment consultants, analysts, auditors and others. Lang, Lins and Miller (2003) show that analysts, being experts in evaluating the companies' growth opportunities can significantly affect a company's access to finance by shaping investors' opinions. One of the company characteristics that the investment industry pays considerable attention to is corporate governance (Hebb and Wójcik 2004). Siegel (2003) shows that US-listed Mexican companies that engaged in bad governance practices during the Mexican crisis of 1994-95 were effectively cut-off from access to finance in the future, while companies with better practices in this period enjoyed subsequent reputational benefits. Siegel claims that reputational bonding is actually much more important than legal bonding.

To be sure there are many other motives for cross-listing beyond access to external finance, let alone bonding. Companies may cross-list to enhance their visibility in foreign markets (Baker et al. 2002), gain more exposure to specialised analyst community that can better appreciate a company's business and growth opportunities, or to extend the trading hours of its shares by cross-listing in a different time zone (Karolyi 2004; Pagano et al. 2002). In other words, deciding whether and where to cross-list a company may not care much about the implications of cross-listing for access to external finance but rather consider export markets, cultural and geographical proximity or industrial specialisation (Sarkissian and Schill 2004). Nevertheless, even a company uninterested in improved access to external finance, should it decide on crosslisting on a stock market with stricter corporate governance requirements than the home market, does become subject to legal and reputational pressure and is likely to account for the forgone private benefits of control and will definitely account for the direct corporate governance related costs.

The simple conceptual framework presented here is illustrated in figure 1 . It should be noted that we could also apply this framework to the relationship between disclosure/transparency and cross-listing. Here, the dilemma faced by management and controlling shareholders is that while disclosure is costly, it can improve the credibility of cash flows and in general the perception of company's prospects by outside investors (Stulz 1999). In other words, disclosure reduces the information asymmetry between investors and company insiders (Merton 1987). In analogy with the promise to forgo private benefits, the company may decide to bond its promise of improved disclosure via a foreign listing in a stricter disclosure regime. The stricter character of the host regime can be realised through both legal and reputational pressure (Healy and Palepu 2001). Bushman et al. (2004) distinguish between financial transparency and governance transparency. In this paper the nature of empirical data allows us to cover governance transparency but not financial transparency. We are however aware of the close relationship between disclosure and corporate governance as well as the significance of the former for the relationship between corporate governance and crosslistings.

To be sure, the simple framework linking corporate governance and cross-listing is a part of broader processes of financial globalisation including financial liberalisation, diversification of investment portfolios, rise of institutional investors, and growing international competition between financial intermediaries including stock exchanges. The shift away from pay as you go to funded pension systems, for example, turns millions of people directly or indirectly, via investment funds, into minority 
shareholders (Clark 2000 and 2003) creating pressure on companies to become more minority shareholder friendly. Beyond financial sector itself, product market competition can also directly affect private benefits and corporate governance. It is because with more product market competition prices are closer to costs, leaving less room for private benefits to be extracted (Dyck and Zingales 2004). A powerful role is also played by technology affecting the nature of equity trading, and by social norms affecting the actual expropriation of minority shareholders. While we are aware of these multiple forces influencing corporate governance and cross-listings, our simplified framework leads us to some testable hypotheses presented in the following section.

\section{Hypotheses}

How does corporate governance of U.S.-cross-listed European companies compare to corporate governance of companies from the same country that do not cross-list in the U.S.?

Let us start with companies that already cross-listed in the US, and therefore are subject to the pressure of the U.S. legal and reputational corporate governance regime. Could this pressure make corporate governance of cross-listed companies more minority shareholder oriented? Can a U.S. regime provide any additional discipline compared to the home regime? ${ }^{2}$ Coffee (1999) claims that once an issuer lists on a U.S. exchange the U.S. securites laws become broadly applicable to it. "This is critically important, because the U.S. securities laws do not simply require heightened disclosure and more rigorous financial reporting; rather, they also seek to reduce agency costs in ways that particularly inhibit controlling shareholders and that are not closely paralleled by European law" (Ibid, 683). Of course, one can question the extent to which the U.S. securities laws are actually enforced in relation to foreign issuers (Licht 2004). Nevertheless, recent research lends support to the position of the U.S. market as one with relatively strict minority shareholder oriented corporate governance. Doidge, Karolyi and Stulz (2004) found that in 1997 foreign companies with shares cross-listed in the U.S. had Tobin's q ratios $16.5 \%$ higher than q ratios of non-cross-listed firms from the same country. ${ }^{3}$ The finding on higher valuation held for nearly all European countries considered in their study. They suggest "that a U.S. listing reduces the extent to which controlling shareholders can engage in expropriation and thereby increases the firm's ability to take advantage of growth opportunities" (Ibid, 1).

Doidge (2004) analysed voting premium, defined in simple words as the difference between the price of shares with high voting rights and those with low voting rights. He found that non-U.S. firms that cross-list in the U.S. have voting premiums that are $43 \%$ lower than non-U.S. firms that do not cross-list. As the majority of countries covered in his study are European, it is reasonable to assume that the results would hold for them. According to Doidge this evidence "supports the bonding hypothesis: cross-listing in the U.S. improves the protection afforded to minority investors and decreases the private benefits of control" (Ibid, 1). Finally, Reese and Weisbach (2002) show that cross-listings of non-US firms in the U.S. are followed by an increase in equity offerings. Their findings apply to companies from European countries. In the spirit of the previous papers they conclude "the desire to protect shareholder rights appears to be an important reason why some non-U.S. firms cross-list in the U.S." (Ibid, 1). The

\footnotetext{
${ }^{2}$ Notice that the U.S. regime does not have to be stricter overall to result in a better protection of minority shareholders in cross-listed companies compared to those non-cross-listed. See explanation in section four.

3 Tobin's q was computed as ((Total Assets-Book Equity)+Market Value of Equity)/Total Assets (Doidge, Karolyi and Stulz 2004).
} 
combined evidence of these and other research projects (Miller 1999, Pagano et al. 2001) leads us to hypothesise that corporate governance of European firms cross-listed in the U.S. should be more minority shareholder oriented than corporate governance of firms that do not cross-list in the U.S.

We will now move to the relationship between corporate governance of U.S. crosslisting and non cross-listing companies before cross-listing takes place. It is important to distinguish between the period before a company decides to cross-list, and the period after it decides but still before the actual cross-listing. In the latter period we expect the hypothesis on corporate governance advantage of cross-listing companies to hold because a company needs to prepare themselves in terms of corporate governance for cross-listing. A hypothesis is more difficult to formulate in the period before the decision to cross-list is made. Imagine two Italian companies, both contemplating increased access to equity finance. Assume that if they want to improve access to finance they would need to cross-list in the U.S. as there is no possibility of bonding in Italy. How would the starting level of minority shareholder oriented corporate governance affect their choice whether to cross-list? On the one hand, cross-listing for the company with worse corporate governance would imply higher costs of forgone private benefits, and higher direct costs of cross-listing related to corporate governance. On the other hand, worse corporate governance implies worse access to finance, and higher benefits of increased access to finance as a result of cross-listing. Overall, even if we assume the value of investment opportunities and all other motives for cross-listing to be the same for both companies, the relationship between corporate governance prior to the decision about cross-listing and the likelihood of cross-listing is ambiguous. The prediction is easier to make if managers and/or controlling shareholders of a company are not interested in improved access to finance but consider cross-listing for other reasons. Then the sum of the costs of forgone benefits of control and direct corporate governance related costs would be weighed against benefits of cross-listing unrelated to access to finance, and hence unrelated to the starting level of corporate governance. As a result, companies with better starting level of corporate governance would be more likely to cross-list as they would face lower costs of forgone benefits. In a sample of companies with mixed motivations for cross-listing, we may expect companies that cross-list to have more shareholder oriented corporate governance even before they make cross-listing decision. ${ }^{4}$

The relationship between corporate governance and the type of U.S. cross-listing We can refine our hypothesis on the relationship between corporate governance and the U.S. cross-listing status of European companies by considering the type of cross-listing. There is a large body of literature on corporate governance and related reporting requirements faced by foreign companies when they list their shares in the U.S. markets. Here we briefly summarise the most relevant points.

There are two ways in which a foreign company can list its shares in the U.S. It can use American Depositary Receipts (ADRs) or list its shares directly on a stock exchange. ${ }^{5}$

\footnotetext{
${ }^{4}$ What could further complicate the relationship between cross-listing and corporate governance are the spill-over effects. According to Stulz (1999) financial globalisation increases the monitoring of management also in these firms that do not take part in global capital markets. This is because nonparticipation sends a negative signal to markets. If non-cross-listed companies indeed adjust their corporate governance not to lag behind the cross-listed companies, the higher corporate governance rating of cross-listed firms in relation to those non-cross-listed should decrease or even fade away with time.

${ }^{5}$ For the purpose of this paper no distinction is necessary between ADRs and Global Depositary Receipts or between sponsored and unsponsored ADRs.
} 
Few European firms cross-list directly, and requirements they face are essentially the same as for ADRs (Reese and Weisbach 2002). ADRs are negotiable certificates of ownership of shares of a foreign firm traded in the U.S. While the shares are deposited in a depositary bank in the firm's home country, an ADR holder has all dividend and voting rights stemming from the underlying shares.

Issuers can choose between four different types of ADRs. Rule 144A ADRs allow the sale of foreign firm's shares only to sophisticated institutional investors. These ADRs do not have to be registered with the Securities and Exchange Commission (SEC) and are exempt from U.S. reporting requirements. Level I ADRs are traded in the over-thecounter market, outside stock exchanges, require minimal SEC registration and are also exempt from U.S. reporting requirements. Level II ADRs are traded on a U.S. stock exchange (NYSE, NASDAQ or Amex), and subject to full SEC registration and U.S. reporting requirements, including a timely submission of financial statements and their reconciliation to the U.S. Generally Accepted Accounting Principles (GAAP). Level III ADRs follow similar rules as Level II ADRs but as they can raise capital in the U.S. through a public offer of new shares they face additional reporting requirements including a prospectus detailing the risks of the offer. For Level II and III ADRs, on the top of the SEC registration and reporting requirements come the corporate governance requirements of stock exchanges where they list. These can cover such issues as independent directors, audit committee or provision of proxy statements to shareholders.

We can infer that the legal pressure is incomparably higher for foreign companies with Level II or III ADRs than for those without a U.S. stock exchange listing. It is reasonable to expect the reputational pressure to be higher for these firms as well. As a result we would expect companies with a U.S. stock exchange listing to have more minority shareholder oriented corporate governance than companies without a stock exchange listing. This expectation can be confronted with existing empirical evidence. Doidge, Karolyi and Stulz (2004) demonstrate that the Tobin's q premium of U.S. cross-listed firms over non-cross-listed firms was much higher for companies with an exchange listing, though it still existed for companies with Level I or Rule 144A ADRs. Doidge (2004) however, shows that foreign firms without a U.S. stock exchange listing do not have lower voting premiums than firms that do not cross-list. Consequently his conclusion is that bonding mechanism does not apply to Level I or Rule 144A ADRs. Thus, while our expectation that European firms with a U.S. stock exchange crosslisting (via Level II or III ADRs) have better corporate governance than firms from the same country that do not cross-list in the U.S., the relationship between European firms with Level I or Rule 144A ADRs and companies without any U.S.-listing can be expected to be weaker or non-significant.

The relationship between corporate governance and cross-listing within Europe

We now turn to the potential impact of cross-listing of European companies within Europe on their corporate governance. First we need to consider whether in terms of corporate governance any European stock exchange requires from foreign companies more than is required from them at their home exchange. The existing research focuses on financial disclosure rather than corporate governance. Cantale (1998) investigates the stock price reaction to the announcement that a firm from continental Europe or the UK intends to list on the NYSE, London Stock Exchange (LSE) or the Paris Stock Exchange. The abnormal return was the highest for the NYSE, moderate for the LSE, and the lowest but still positive for Paris. The author suggests that this pattern can be explained by disclosure requirements, which were the strictest on the NYSE, followed 
by the LSE and Paris (see also Saudagaran and Biddle 1995). Coffee (2002) mentions the LSE next to the NYSE as a potential destination of cross-listed companies with high corporate governance standards. However, Poser (2001) reports that unlike the NYSE, the LSE has not emphasised listing or disclosure standards as a competitive strategy.

Another factor to be considered here is the mutual recognition principle incorporated in the European legislation regulating cross-listings (Coffee 1999). In simple words, the meaning of the principle is that what is sufficient for a company to list in one member country should be sufficient in any other member country. To the extent the principle of mutual recognition affects the actual practices of European stock exchanges, it would presumably result in none or little corporate governance impact of cross-listing, at least in the sense of legal pressure. The potential reputational pressure resulting from a European cross-listing is a separate issue. On the one hand, we could expect companies cross-listing on stock exchanges where domestic corporate governance standards are high to be under stronger reputational pressure than companies cross-listing in markets where domestic standards are less strict. For that reason, we could expect firms crosslisting on the LSE to have more minority shareholder oriented corporate governance than firms cross-listing in Switzerland. On the other hand, the difference could fade away if reputational intermediaries from London could exert their pressure on large European corporations irrespective of whether they cross-list in London, Switzerland or not at all. To summarise, due to scarce and mixed evidence we would not expect a significant effect of cross-listing within Europe on corporate governance.

\section{Data and methodology}

We will present three datasets used in this paper: data on corporate governance of European companies, data on their cross-listings in the U.S. and within Europe, and data on their company characteristics applied in multivariate analysis on the relationship between corporate governance and cross-listing. The first part of the section focuses on the sources and features of each of the datasets, and the second part presents the sample. Corporate governance

The paper uses proprietary data on corporate governance ratings of the largest European companies in 2000 and 2003 provided by Deminor Rating SA (Deminor Rating), a corporate governance rating agency headquartered in Brussels, with offices in major European cities. The objective of Deminor Rating is to provide information to investors about a company's corporate governance standards and practices. While selected aggregate results of Deminor rating activity are available in the public domain, through published reports and website, details are available on subscription. The main users of Deminor ratings are institutional investors, both European and non-European, who use the ratings to inform their investment decisions. It should be mentioned that Deminor

Rating's customers are often if not mostly institutions that invest money on behalf of millions of individual small shareholders.

Deminor Rating distinguish between four building blocks of corporate governance, referred to as categories. The first category "shareholders' rights and duties" captures the extent to which shareholders, particularly small ones, have impact on actions undertaken by the company. The second category "take-over defences" assesses if the company implements any barriers against potential hostile take-overs, thus sheltering the management from the threat of replacement. "Disclosure" measures the availability and quality of information on corporate governance. Within the fourth category "board structure and functioning" Deminor Rating evaluate such criteria as the independence of board members as well as their remuneration. Each category consists of sub-categories, described in appendix one, and sub-categories consist of numerous criteria totalling 
over 300, highlighting the robustness of Deminor Rating's methodology. Deminor Rating analysts use exclusively publicly available information, with the main sources being corporate websites, stock exchange announcements and press articles. For each category a company can score between 0 and 10 points, and their sum gives the total corporate governance score. On the basis of the scores, referred to as notations, Deminor Rating assign a rating from 1 to 5 for each category. In this paper we use notations as they provide finer detail, however in order to reflect the fact that notations are an intermediate step in the rating process, throughout the paper we will refer to them as ratings.

The ratings are prepared annually, with the first rating in its current format prepared in 2000. The year of the rating stands for the year of its preparation. In this paper we use ratings for 2000, 2001, 2002, and 2003, which is the last rating available. Summarising the value of Deminor ratings for our project, we should stress their up-to-date character, and the possibility of analysing the component parts of corporate governance. Moreover, the rating is designed and conducted from the perspective of minority shareholders, making it appropriate for testing our hypotheses.

Cross-listings

Data on cross-listings in the U.S. was obtained from the ADR dataset available on the website of JP Morgan Chase \&Co. This dataset includes the type (Level I, II, III or Rule 144A), and the effective year of the ADRs. This data was supplemented with data on terminated ADRs available on the Bank of New York website.

Data on cross-listings within Europe was obtained partly through direct enquires with the major European stock exchanges but mostly from the database Amadeus, provided by Bureau van Dijk. Due to the fact that Amadeus database does not give the year of cross-listing, and offers limited coverage of financial sector companies, data on crosslistings within Europe is restricted to non-financial companies cross-listed at the end of 2003.

\section{Company characteristics}

This dataset involves corporate characteristics other than corporate governance or crosslisting status. The selection of variables was guided by existing research, in particular Pagano et al. (2002) who found the cross-listing decision of European companies to be associated strongly with the following variables: percentage of foreign sales in total sales, asset growth rate in the past, price to book value ratio (PBV), dummy representing high technology dummy, and value of total assets. Data on these variables was obtained from FactSet database. These variables will be used in multivariate analysis of the relationship between cross-listing and corporate governance in section seven, where we present the descriptive statistics on these variables, while their detailed definitions are presented in appendix two.

\section{Sample}

Since Deminor ratings represent the most unique of the datasets used in the paper, the sample of companies under consideration is determined by the availability of data on corporate governance. Deminor Rating aim at rating all companies that are constituents of the FTSE Eurotop 300 index. The index consists of the largest 300 European companies according to market capitalisation (stock market price multiplied by the number of outstanding shares). ${ }^{6}$ In some cases Deminor Rating are not able to obtain sufficient information to rate a company, often due to a major reorganisation of the

\footnotetext{
${ }^{6}$ Strictly speaking, the index consists of the largest 300 eligible European companies. To be eligible a company must either have a free float of at least $15 \%$ or have a free float above $5 \%$ and market capitalisation greater than USD 5bn (USD 2.5bn if it is incorporated in an emerging market country). For details of this and other European FTSE indices see FTSE (2004).
} 
company in question e.g. a merger or acquisition. In total, there were 361 companies rated by Deminor Rating at least once between 2000 and 2003, 257 rated in 2000, and 284 rated in 2003.

Table one presents the sample by country of incorporation and according to their U.S. cross-listing status. Based on our hypotheses we distinguish between companies traded on a U.S. stock exchange (Level II or III ADRs) and those traded outside a U.S. stock exchange (Level I and Rule 144A ADRs). Companies in the sample are incorporated in 17 European countries, 15 members of the European Union at the end of 2003, plus Norway and Switzerland, with nearly $90 \%$ of them incorporated in one of eight countries specified in the table. There were no companies from $2004 \mathrm{EU}$ accession countries or the former Soviet Union in the sample. There are 45 companies that had Level I or Rule 144A ADRs at the end of 2003 for which we do not know the year of cross-listing. These companies are presented in a separate column for 2000. Between 2000 and 2003 the number of companies with Level II or III ADRs increased from 92 to 120 or from $36 \%$ to $42 \%$ of the total sample, indicating that the migration of European companies to U.S. stock markets documented by Pagano et al. (2002) for the 1990s continued at the start of the new millennium.

Table two presents the non-financial companies in the 2003 sample according to their cross-listing status within Europe. There were only 30 companies for which we did not identify any European cross-listing at all. A European cross-listing was defined as a cross-listing on any stock exchange of the 17 countries of companies' origin. In total we identified 589 cross-listings, which gives nearly 3 cross-listings per company. Four stock exchanges that attracted the largest number of cross-listings are presented in the table, with the Swiss Exchange and the Deutsche Börse in the lead, followed by the London Stock Exchange, and the Euronext Paris. To complete the presentation of the data table three shows corporate governance ratings of the sample companies by country in 2000 and 2003. A detailed analysis of the dynamics of European corporate governance ratings by country and sector is subject of a separate paper (Wójcik 2004). There are however several observations that provide important background for this paper. First, the ratings differ significantly between countries, with the UK by far in the lead. Second, the total median rating of every country increased considerably, with the exception of Germany. Third, dynamics of ratings differs significantly between different aspects of corporate governance, with disclosure and board structure and functioning exhibiting the highest increase. Summarising, we should keep in mind, that analysing the relationship between corporate governance and cross-listing, we are assessing a relationship between complex and dynamic phenomena.

\section{Corporate governance and U.S. cross-listing of British, French, German, and Italian companies}

We start analysing the relationship between U.S. cross-listing and corporate governance by focusing on the British, French, German, and Italian companies in 2003. Companies from these four countries account for nearly two-thirds of our 2003 sample. Table four presents the average and median ratings for each type of U.S. cross-listing and each category of corporate governance.

It is striking that in each country the average total corporate governance rating is highest for companies with Level II or III ADRs, lowest for firms with no U.S. cross-listing, with Level I or Rule 144A cross-listings in the middle of the ranking. If we turn from averages to median values the advantage of Level I or 144A ADRs over firms with no U.S. cross-listings holds only for French companies, but the advantage of Level II or III ADRs over firms with no U.S. cross-listing remains strong. For Germany and Italy the 
median total corporate governance rating of companies without a U.S. cross-listing is by approximately 3.5 points lower than median rating of firms with ADRs traded on a U.S. stock exchange, and these medians are statistically different from each other. In France the differences between the types of U.S. cross-listing are large but not statistically significant in the case of total corporate governance rating. They are however statistically significant for disclosure as well as board structure and functioning. These two building blocks of corporate governance appear to be the main contributors to the advantage of U.S. cross-listed companies in other countries as well.

A comparison between table four and table three indicates the importance of differences in corporate governance ratings related to country-specific factors. If we were to put the four countries in the order of descending total corporate governance ratings the order would be the same (UK, France, Italy, and Germany) irrespective of the U.S. crosslisting status. In other words, the Italian or German U.S. cross-listing elite (companies with Level II or III ADRs) have median total corporate governance ratings considerably higher than other companies in their home countries, but these medians are still lower than the median rating for all French companies, including those without any U.S. cross-listing, and much lower than the median for British companies without any U.S. cross-listing.

Results for the UK are particularly interesting. We could expect British companies to have little problem in adjusting to the U.S. regime of corporate governance. Not only is the overall level of corporate governance ratings high in the UK but some aspects of it e.g. the takeover rules are actually considered superior to the U.S. system (Ferrell 2003). Nevertheless, the British companies cross-listing in the US, including those with Level I or 144A ADRs, do have marginally higher corporate governance ratings than companies without a U.S. cross-listing. In addition, the pattern holds for every category of corporate governance. In our opinion these findings lend support to the following view. The U.S. regime does not have to be stricter in all its aspects or even overall in order to result in a better protection of minority shareholders in cross-listed companies compared to those non-cross-listed. Cross-listing company does not escape the domestic regime, instead it becomes subject to additional legal and reputational pressure. Thus, by cross-listing in a regime which covers an area of corporate governance uncovered by the domestic regime, the governance of the company could change, even if overall the domestic regime is more strict.

To summarise, in this section we have identified the first traces of evidence consistent with our hypothesis on the relationship between corporate governance and U.S. crosslisting status, as well as that on the role of the type of U.S. cross-listing. Companies with U.S. cross-listings tend to command higher corporate governance ratings. In the following section we continue to explore these hypotheses, extending our analysis to the full sample of companies.

\section{Corporate governance before and after U.S. cross-listing}

We now extend the comparison between companies that cross-list in the U.S. with those that do not to all countries covered in our sample. The top part of table five reports the differences in median values of corporate governance ratings between companies with Level I or Rule 144A ADRs and those that did not have any U.S. cross-listing during the whole sample period 2000-2003. The lower part of the table reports the differences in medians between firms with Level II or III ADRs and those without any U.S. crosslisting. The sample includes data on corporate governance variables from 2000 to 2003 covering 235 companies for the top part of the table (142 with Level II or III ADRs and 97 without any U.S. cross-listing, less four companies that terminated their listings), and 
184 for the lower part (77 with the known year of Level I or Rule 144A cross-listing and 97 without any U.S. cross-listing). Columns give the differences in medians in the years $-2,-1,0,+1,+2,+3$ or more - relative to the year of cross-listing. The differences are computed by an OLS regression, where the corporate governance variable of interest is regressed on a relative-listing-year dummy, controlling for calendar year and country of incorporation. The relative-listing year dummy for year $+n(-n)$ takes the value one for observations taken $\mathrm{n}$ years after (before) the year in which the company is crosslisted in the US. A separate Least Absolute Value regression is run for each cell in the table. The value reported is the coefficient of the relative-listing-year dummy. It is this coefficient to which we refer as the difference in median values of corporate governance, following the approach by Pagano et al. (2002).

Starting with companies with Level II or III ADRs, we find them having significantly higher total corporate governance ratings than firms without a U.S. cross-listing irrespective of the relative year of cross-listing. In other words, their corporate governance advantage starts at least two years before the year of cross-listing and remains at least three years afterwards. Corporate governance categories that contribute to the advantage of firms with Level II or III ADRs are take-over defences, disclosure, and board structure and functioning. In contrast, the ratings for shareholders' rights and duties do not seem to be higher in firms with Level II or III ADRs. Interpreting this finding we should mention that one of the major criteria within the category of shareholders' rights and duties is whether a company has a one-share one-vote capital structure. U.S. stock exchanges or at least the NYSE do not require foreign companies to follow this principle. From our findings it appears that there is no effective non-legal pressure that would make European companies cross-listing on U.S. stock exchanges follow the one-share one-vote principle. The result on firms with Level II or III ADRs having systematically higher disclosure ratings is least surprising. Previous research has suggested that U.S. stock exchange cross-listed companies have higher financial disclosure standards (Khanna et al. 2004). Our results show that the advantage of foreign firms cross-listed on a U.S. stock exchange applies also to disclosure on corporate governance.

Continuing the comparison between companies with Level II or III ADRs and those that do not cross-list at all, let us consider the pattern of the coefficients reported in table five over time. In fact, for take-over defences, disclosure and total corporate governance companies with Level II or III ADRs enjoy higher ratings of a similar magnitude irrespective of the relative year of cross-listing. Importantly we do not see firms with Level II or III ADRs gaining or strengthening their advantage in terms of corporate governance after cross-listing. This finding leaves the issue of causality between corporate governance and U.S. cross-listing open. Perhaps higher ratings of cross-listing firms one or two years before the actual cross-listing reflect the process of preparation for cross-listing. On the other hand, higher ratings can indicate that companies with more minority shareholder friendly corporate governance are more likely to decide on a U.S. cross-listing. The latter explanation is consistent with the findings by Bancel and Mittoo (2001) who showed that European firms with higher level of financial disclosure perceive net benefits of listing to be higher, because their perceived costs of crosslisting related to increased disclosure are lower.

To be sure, higher ratings of cross-listing companies before the time of cross-listing can be driven by both the preparation and self-selection arguments simultaneously. To figure out the relative contribution of each one would need to know the time when a company decides to cross-list in the U.S. We should however point to a finding that speaks in favour of seeing U.S. cross-listing as having an impact on corporate 
governance. The advantage of firms with Level II or III ADRs in terms of board structure and functioning becomes significant one year before the year of cross-listing and increases after the cross-listing. We could argue that board structure and functioning is a deeper, more substantive and more difficult to change aspect of corporate governance than disclosure. If this is true it is not surprising to see board structure and functioning reacting to a cross-listing decision and the actual cross-listing event more slowly than other aspects of corporate governance.

We now turn to the comparison between firms with Level I or Rule 144A ADRs and those without any U.S. cross-listing. Nearly all coefficients are positive and many of them including those for total corporate governance are significant. In analogy with the results for Level II or III ADRs, the main contributors to the advantage of U.S. crosslisting companies are ratings for takeover defences and disclosure. The coefficients for board structure and functioning become significant only 3 or more years after crosslisting, which adds to the tentative evidence on the impact of U.S. cross-listing on corporate governance. Otherwise, the pattern of the coefficients over time is puzzling. In particular, the differences in medians are not significant for any category of corporate governance in the year of cross-listing. This may be due to the fact that for a number of companies we do not know the year of Level I or Rule 144A cross-listing, what made the size of the sample analysed in this section smaller.

To summarise, the results of this section suggest that firms that cross-list in the U.S. have higher corporate governance ratings than companies that do not cross-list in the US. This advantage is more consistent for companies with Level II or III ADRs than for those with Level I or Rule 144A ADRs. While these results echo the findings of the preceding section, the additional contribution of this section is to show that the corporate governance advantage of firms cross-listing in the U.S. exists both prior and after the cross-listing. All these results are consistent with our hypotheses. It remains ambiguous to what extent companies cross-list because they have higher ratings or have higher ratings because of cross-listing. Evidence in support of the latter explanation involves companies with U.S. cross-listings increasing their advantage over firms without a U.S. cross-listing over time in terms of board structure and functioning. In the following section we explore whether the findings on the relative corporate governance of companies cross-listing in the U.S. can be sustained if we account for other factors that affect cross-listing decisions.

\section{U.S. cross-listing and corporate governance: multivariate analysis}

Having analysed the bivariate relationships between corporate governance and the U.S. cross-listing status for the largest European economies and the whole sample, in this section we account for the impact of other corporate characteristics that affect crosslistings. Pagano et al. (2002) found that European companies cross-listing in the U.S. between 1986 and 1997 did indeed have some specific features compared to European companies cross-listing within Europe or firms without any cross-listing. The most distinctive features of firms cross-listing in the U.S. were the following: large size (measured as the logarithm of total assets), export orientation (measured as the percentage of foreign sales in total sales) ${ }^{7}$, high asset growth rate in the past as well as strong growth prospects (measured as price to book value ratio). In addition, firms cross-listing in the U.S. tended to belong to high technology sector.

\footnotetext{
${ }^{7}$ For the role of export orientation in cross-listing decisions see also Saudagaran 1988.
} 
In this section we ask whether the relationship between corporate governance and the U.S. cross-listing status identified in the preceding sections holds after we account for other corporate characteristics that affect U.S. cross-listing decision. We use multinomial logistic regression, with the dependent variable consisting of three categories of companies: the first category covers companies with Level II or III ADRs; the second category - companies with a Level I or Rule 144AADRs; the third category companies with no U.S. cross-listing. The objective of the multinomial logistic regression applied here is to assess the relationship between a company's propensity towards a given U.S. cross-listing status, and a set of predictor variables. The predictor variables include corporate governance ratings, country dummies, as well as companylevel variables suggested by Pagano et al. (2002): the percentage of foreign sales in total sales, asset growth rate, price-to-book ratio, high tech dummy, and total asset value (logarithmically transformed due to large absolute values of total assets). We run separate regressions for 2000 and 2003, and for each of the five corporate governance ratings. The dependent variable i.e. the U.S. cross-listing status of European companies in 2000 and 2003 was presented in table one. The descriptive statistics for the predictor variables are presented in table six. Definitions of corporate governance variables are presented in appendix one, and details of other corporate variables in appendix two.

As a preliminary diagnostic test of whether the relationship between corporate governance ratings and U.S. cross-listing status may be driven by other company characteristics that are strongly correlated with the ratings, we analysed bivariate correlations of the predictor variables included in the model. We did not find any Spearman's rank correlation coefficient to be higher than $0.3 .{ }^{8}$ Table seven presents the results of the logistic regression for corporate governance ratings in 2003 and 2000. The results start with statistics on model fit and proceed to the list of predictor variables with their regression coefficients and significance statistics. The coefficients are estimated through an iterative maximum likelihood method. We report $\operatorname{Exp}(\mathrm{B})$ coefficients defined as the effect of the predictor variable on the odds ratio (the probability of the event divided by the probability of the non-event). If $\operatorname{Exp}(B)$ equals e.g. 2 it means that an increase of the predictor value by 1 increases the odds of the event by a factor of 2 . A coefficient value below 1 implies that the event is less likely with the increase of the predictor variable. If $\operatorname{Exp}(\mathrm{B})$ equals 1 it means that there is a 50/50 chance that the event will occur with a small change in the predictor variable. We should note that while $\operatorname{Exp}(B)$ coefficients for continuous variables tend to be close to 1, it does not mean they are insignificant (Hosmer and Lemeshaw 2000). To judge the significance of coefficients we use the reported significance statistics based on the significance level of the Wald statistic (the squared ratio of the coefficient to its standards error). If the significance level is small, the coefficient is different from zero.

The results on predictor variables are presented for Level II or III ADRs, and Level I or Rule 144A ADRs. These two sets of results describe a statistical profile of companies cross-listing in the U.S. in one or the other form in relation to companies without any U.S. cross-listing. The category of no U.S. cross-listing is a reference category in our model. If U.S. cross-listing is related to corporate governance ratings after we control for the considered corporate characteristics and the country of origin, we would expect the coefficients for corporate governance predictors to be higher than 1 and statistically

\footnotetext{
${ }^{8}$ We did additional tests for multicollinearlity by analysing covariance coefficients and Variance Inflation Factors. No problems were identified. We have also performed regression analyses with block variables and found that the addition of corporate governance variables adds to the explanatory power of the model. Finally, we performed regressions without country dummies. The values of coefficients were changed but our conclusions regarding their significance remained unchanged.
} 
significant. The model fit statistics show that each of our regression models is significant at $1 \%$ level according to Chi-square statistic. If using our set of predictor variables was no better than guessing the U.S. cross-listing status of a company, the percentage of correct predictions from our regressions would be approximately $33 \%$ for each of the three categories of U.S. cross-listing. The actual percentage of correct predictions in our regressions ranges from $39 \%$ to $86 \%$.

Focusing on the predictor variables our results are largely consistent with the findings by Pagano et al. (2002). In both 2000 and 2003 companies with Level II or III ADRs tend to be larger, more export oriented, and more high-tech than companies without a U.S. cross-listing. The coefficients for asset growth rate and PBV however were mostly statistically insignificant. This is in contrast to Pagano et al. (2002) who found U.S. cross-listed companies to have higher growth rates and PBV ratios. Interpreting this inconsistency we should consider the fact that their sample covered all European companies with a U.S. cross-listing while our sample covers only the largest European companies, amongst which we would expect a more stable growth records and prospects. No non-corporate governance variable, with the exception of foreign sales percentage in 2000, was a significant predictor of a U.S. cross-listing via Level I or Rule 144A ADRs. This could be explained by the fact that cross-listing outside a stock exchange involves much lower costs, implying less need for a company to be large to be able to afford a cross-listing, and is not associated with enhanced access to high-tech financing, that could be gained through a stock exchange listing, particularly on Nasdaq. Let us turn to the relationship between the U.S. cross-listing status and corporate governance variables. In 2000 none of the governance variables was a significant predictor of a Level I or Rule 144A U.S. cross-listing. In 2003 though, this type of cross-listing could be associated with higher takeover defences rating, much higher boards structure and functioning rating and a higher total corporate governance rating. Regarding cross-listings via Level II or III ADRs, in 2000 the only governance variable that could be associated with this type of cross-listing at a $1 \%$ significance level was disclosure, while board structure and functioning was a significant predictor at $10 \%$ level only. The results for 2003 indicate a much stronger relationship between corporate governance and the propensity of firms to cross-list using Level II or III ADRs, with all ratings except shareholders' rights and duties being significant predictors of this type of cross-listing. In $2003 \operatorname{Exp}(\mathrm{B})$ coefficients for disclosure and board structure were over 4.8 and 3.7 respectively, both significant at $1 \%$ level. Thus, a unit change in a company's disclosure and board rating increases the odds of this company being crosslisted on q U.S. stock exchange nearly five and four times respectively.

The logistic regression leads us to three major findings. First, after we control for a number of corporate characteristics affecting the U.S. cross-listing decision, European firms with higher corporate governance ratings do have a higher propensity to cross-list via Level II or III ADRs. Firms with Level II or III ADRs can be associated in particular with higher disclosure ratings, what corroborates the results of Khanna et al. (2004) showing that companies from Asia-Pacific and Europe interacting with the U.S. markets tend to command higher transparency and disclosure scores developed by Standard\&Poors. However, the association between U.S. stock exchange cross-listing and high corporate governance rating goes beyond disclosure, and most significantly involves also higher board structure and functioning rating. Second, a Level I or Rule 144A U.S. cross-listing seems to make a difference to corporate governance as well, and particularly to board structure and functioning. Nevertheless, the association of corporate governance ratings with Level I or Rule 144A cross-listing is much weaker 
than that with Level II or III cross-listings. Both of these findings are consistent with our hypotheses.

The third major finding refers to the strengthening of the relationship between corporate governance and the U.S. cross-listing status between 2000 and 2003. We can offer two speculative explanations for this pattern. While the year of 2000 was in the tail of the U.S. stock market boom, 2003 was definitely a post-boom year. We presume that in a bear market, the attraction and potential benefits of a U.S. cross-listing are smaller than in a bull market. Since lower corporate governance standards imply higher costs of cross-listing (both direct corporate governance related costs and indirect costs of foregone benefits of control), we can expect companies cross-listing in bear market to have on average higher corporate governance standards than companies cross-listing in a bull market. Another speculative explanation involves the legal and reputational pressure on companies cross-listed in the U.S. being higher in 2003 than in 2000, leading to a stronger relationship between corporate governance and U.S. cross-listing status in 2003. With the growing awareness of corporate governance issues following the U.S. corporate scandals, and legal changes with the Sarbanes-Oxley Act (SOA) of 2002 in the lead such a speculation is plausible. ${ }^{9}$

\section{Corporate governance and cross-listing within Europe}

There are very few companies in the sample that do not cross-list within Europe, and so our findings thus far already suggest that companies cross-listed within Europe have lower corporate governance ratings than those cross-listed in the U.S. In this section we explore the relationship between corporate governance and cross-listings within Europe by comparing country-adjusted corporate governance ratings of companies cross-listed on European stock exchanges, while controlling for their U.S. cross-listing status. To obtain a country-adjusted rating for a company we subtract from its rating the mean rating for all companies incorporated in the same country and express the resulting difference as the percentage of the mean rating of this country. In other words, a country-adjusted rating of a company tells us by how many percentage points a company's rating differs from the mean rating of the country where the company is incorporated.

Recall that the analysis can be conducted only for the sample of non-financial companies in 2003. We considered four major European stock exchanges that attracted the largest number of foreign European firms, as well as a category embracing all stock exchanges in all countries the sample companies are incorporated in. Companies with Level I or 144A ADRs and those with no U.S. cross-listing have been aggregated into one category. Table eight reports median values of country-adjusted corporate governance ratings for groups of companies classified simultaneously on the basis of their U.S. cross-listing status and according to whether they cross-list on a particular European stock exchange (or any European stock exchange) or not. We have also included the results of a test assessing the significance of the difference in medians between firms cross-listing on a particular European stock exchange and those that do not cross-list on that exchange. If cross-listing on a particular European stock exchange is to be associated with a systematically higher (lower) corporate governance rating

\footnotetext{
${ }^{9}$ Though the extent to which the SOA applies to foreign issuers is limited, some new stringent corporate governance rules do apply. Examples include the certification of periodic disclosures by directors, and the increased responsibility of auditors. Our time series covering 2003 ratings is too short to test the impact of SOA. See the case of the Swiss company Adecco, cross-listed in the U.S., facing increased legal and reputational pressure in terms of corporate governance after the introduction of the SOA (Simonian 2004).
} 
independently of the relationship between corporate governance and the U.S. crosslisting status, then we would expect companies that cross-list on this particular stock exchange to have a significantly higher (lower) median country-adjusted corporate governance rating than firms that do not cross-list on this exchange.

It appears that firms with any European cross-listing have ratings that are not significantly different from firms that do not cross-list in Europe at all. In fact for companies without Level II or III ADRs the median country-adjusted shareholders' rights and duties rating is lower for companies that do cross-list within Europe than for those that do not. For the Deutsche Börse there are no significant differences between medians. In the case of the London Stock Exchange (LSE) the median country-adjusted disclosure and board structure and functioning ratings are higher for firms cross-listed on the LSE than for those that do not. These differences were however not statistically significant. Moving to the Euronext Paris, the results are similar to those for the LSE, though this time the positive difference for disclosure is significant for firms without Level II or III ADRs. Finally, the results for the Swiss Exchange resemble those for the Deutsche Börse except that a cross-listing on the Swiss Exchange can be associated with lower shareholders' rights and duties rating for companies with Level I, 144A or none U.S. cross-listing.

To summarise, if we were to put the four major European stock exchanges on the spectrum between positive and negative association with corporate governance ratings of cross-listed companies, the list would start with the Euronext Paris, followed by the LSE, the Deutsche Börse, and the Swiss Exchange in the last place. To be correct however, we should stress that notwithstanding the traces of differences between them, all four exchanges would be positioned close to the middle of the spectrum, reflecting a more or less neutral association with corporate governance. In other words, in consistence with our last hypothesis, we have not identified any considerable relationship between corporate governance and cross-listing within Europe.

\section{Conclusions and implications}

In this paper we have assessed the relationship between corporate governance and crosslisting of European corporations. The emphasis has been on cross-listing in the U.S. but our analysis has also covered cross-listing within Europe. Based on a review of recent research on corporate governance and cross-listing we have presented a conceptual framework linking the two phenomena, which allowed us to formulate hypotheses on corporate governance of companies cross-listing in the U.S. versus those without a U.S. cross-listing, the significance of the type of U.S. cross-listing, as well as the role of cross-listing within Europe. Our empirical analysis was based mainly on proprietary data on corporate governance of over 300 European firms, constituents of FTSE Eurotop 300 index, rated by Deminor Ratings SA in the period of 2000-2003. The data was not only up-to-date but also allowed us to differentiate between such aspects of corporate governance as shareholders' rights and duties, takeover defences, disclosure on corporate governance, as well as board structure and functioning.

We found that European companies cross-listing in the U.S. tend to have higher corporate governance ratings than companies from the same countries that do not crosslist in the U.S. This finding was revealed in bivariate analysis and confirmed by multivariate analysis, in which we controlled for other corporate characteristics affecting the cross-listing decision including company size, growth, and export orientation. The advantage of U.S. cross-listing firms does not however extend to all aspects of corporate governance. It is consistent in terms of disclosure as well as boards structure and functioning but does not apply to shareholders' rights and duties. We also 
found that the advantage of U.S. cross-listing firms can be traced back to at least 2 years before the year of their cross-listing in terms of ratings for takeover defences and disclosure, and one year before in terms of board structure and functioning. This may imply that firms are adjusting their corporate governance while preparing for a U.S. cross-listing, but it may also mean that companies cross-listing in the U.S. tend to have higher ratings before they decide to cross-list. Thus, in the relationship between U.S. cross-listing and corporate governance the causation can operate in both directions, which is consistent with a view that companies with less minority shareholder friendly corporate governance face higher direct and indirect costs of cross-listing on a stock market with relatively strict corporate governance requirements.

Regarding the type of U.S. cross-listing, we found that while firms cross-listing via Level II or III ADRs can definitely be associated with total corporate governance ratings higher than companies without a U.S. cross-listing, the advantage of firms with Level I or Rule 144ADRs is weaker and less conclusive. A multivariate analysis for the year of 2000 showed no significant advantage of firms with Level I or Rule 144ADRs over those without a U.S. cross-listing. Analysis for 2003 however shows their advantage in terms of takeover defences and particularly board structure and functioning. Finally, we have assessed the relationship between corporate governance and cross-listing within Europe. While we found traces of higher corporate governance ratings for companies cross-listed on the Euronext Paris and the London Stock Exchange compared to those cross-listed on the Deutsche Börse or the Swiss Stock Exchange, the differences were mostly insignificant. In contrast to the findings on the U.S. cross-listings we found no significant relationship between corporate governance and cross-listing within Europe.

We can assess neither the extent to which European companies cross-listing in the U.S. bond their commitment to more minority shareholder friendly corporate governance nor the extent to which they avoid corporate governance related costs of cross-listing. Nevertheless, our findings allow us to confront the radical versions of both the bonding and avoiding hypothesis. Licht (2001) describes the practices of Israeli companies listing only in the U.S. and avoiding a listing in Israel in order to escape the apparently stricter domestic corporate governance requirements prevailing in Israel. According to our evidence, this extreme form of avoiding corporate governance standards does not apply to European companies cross-listing in the US. First, all companies in our sample had domestic listings. Second, companies that did cross-list in the U.S. tend to have higher corporate governance standards than companies without a U.S. cross-listing. With regard to bonding Coffee (1999) suggests the possibility of a race to the top among stock exchanges raising their corporate governance requirements in order to provide bonding services to companies. As we find no evidence that any major European stock exchange is taking part in such a race, we have to be sceptical about the race-to-the-top hypothesis. ${ }^{10}$ Instead, our findings indicate that both bonding and avoiding are important for understanding the relationship between corporate governance and cross-listing. Two possible avenues for exploring the interaction between the two concepts involve quantitative analysis incorporating data on the timing of cross-listing decisions, and qualitative research in the form of case studies on corporate governance in companies before and after they cross-list.

\footnotetext{
${ }^{10}$ Chemmanur and Fulghieri (2003) propose a model predicting neither a race for the top nor to the bottom, but rather a natural segmentation among exchanges based on optimal regulation. According to the model exchanges with different reputations and listing standards can coexist. A double equilibrium has also been suggested by Coffee (2002). It is puzzling however to find evidence suggesting that the whole Europe is a place for a cross-listing regime that involves low corporate governance standards.
} 
Whatever the extent of bonding and avoiding our findings should concern the European stock exchanges. Whether European firms migrate to the U.S. markets because they have higher corporate governance rating or they have higher ratings because they migrate, European stock exchanges end up sharing their elite customers in terms of corporate governance with the U.S. markets. As a consequence, an American investor interested in European companies with superior corporate governance, may satisfy themselves buying ADRs and have little reason for using the services of European stock exchanges. The threat refers not only to the business of European stock exchanges but is relevant for the future of the European capital markets in general, since sound corporate governance is one of the foundations of strong securities markets (Black 2001).

While we have established the significance of the relationship between corporate governance and U.S. cross-listing of European corporations, we do not intend to exaggerate the impact of cross-listing on corporate governance. This is not only because the direction of causation is mixed but also because cross-listing is one of many forces of globalisation. Other forces operating on corporate governance include product market competition leading to mergers and acquisitions, competition among financial services providers, and international portfolio diversification (Stulz 1999). Moreover, thinking about corporate governance in the context of globalisation we must not lose sight of country-specific factors. The comparison of corporate governance and U.S. cross-listing status in France, Germany, Italy, and the UK revealed that though U.S. cross-listed French, German and Italian firms had higher corporate governance ratings than firms from the same countries that do not cross-list in the US, these ratings were still by far lower than those for the UK firms. Bonding through cross-listing is a form of piggybacking on foreign country's institutions and as such has its limits (Black 2001). Home country institutions remain important for the development of strong international capital markets. ${ }^{11}$

\section{References}

Baker, K., Nofsinger J., Weaver, D. (2002) International Cross-Listing and Visibility. Journal of Financial and Quantitative Analysis 37 (3): 495-521.

Bancel, F., Mittoo, U.R. (2001) European managerial perceptions of the net benefits of foreign stock listings. European Financial Management 7: 213-236.

Bauer, R., Günster, N., Otten, R. (2004) Empirical evidence on corporate governance in Europe: The effect on stock returns, firm value and performance. Journal of Asset Management 5(2): 91-104.

Becht, M., Bolton, P., Röell, A.A. (2003) Corporate governance and control. In Constantinides, G.M., M. Harris, R. Stulz (Eds) Handbook of the Economics of Finance. Elsevier, 1-109.

Benos, E., Weisbach, M. (2004) Private benefits and cross-listing in the United States. Working Paper 10224. Cambridge MA, National Bureau of Economic Research.

Black, B.S. (2001) The legal and institutional preconditions for strong securities markets. University of California Law Review 48: 781-855.

\footnotetext{
${ }^{11}$ Claessens, Klingebiel and Schmukler (2003) show that the level of domestic stock market development of a country and the level of this country's stock market internationalisation are both related positively to economic fundamentals including country-specific corporate governance. They conclude that firms do not internationalise to escape poor domestic environments but rather "better country fundamentals permit firms to internationalise" (Ibid, 1). Our results seem to confirm their findings at a microeconomic level by suggesting that companies with more minority shareholder oriented corporate governance are more likely to internationalise in the form of cross-listing in the U.S.
} 
Bushman, R.M., Piotroski, J.D., Smith, A.J. (2004) What determines corporate transparency? Journal of Accounting Research 42: 207-252.

Cantale, S. (1998) The choice of a foreign market as a signal. Unpublished working paper. New Orleans LA: Tulane University.

Chemmanur, T.J., Fulghieri, P. (2003) Competition and co-operation among exchanges: A theory of cross-listing and endogenous listing standards. Unpublished working paper. Available on www.ssrn.com.

Claessens, S., Djankov, S., Fan, J., Lang, L. (2002) Expropriation of minority shareholders in East Asia. Journal of Finance 57: 2741-2771.

Claessens, S., Klingebiel, D., Schmukler, S.L. (2003) Stock market development and internationalisation: Do economic fundamentals spur both similarly? Unpublished working paper. Available on http://www.worldbank.org/research/bios/schmukler.htm.

Clark, G.L. (2003) European Pensions and Global Finance. Oxford: Oxford University Press.

Clark, G.L. (2000) Pension Fund Capitalism. Oxford: Oxford University Press.

Coffee, J.C. (2002) Racing towards the top? The impact of cross-listings and stock market competition on international corporate governance. Working Paper 205. New York, Columbia Law School, The Center for Law and Economic Studies. Available on www.ssrn.com.

Coffee, J.C (1999) The future as history: the prospects for global convergence and its implications. Northwestern Law Review 93: 641-708.

Deminor Rating (2003) Corporate governance research and rating service. www.deminor-rating.com.

Doidge, C. (2004) U.S. cross-listings and the private benefits of control: evidence from dual-class firms. Journal of Financial Economics 72: 519-553.

Doidge, C., Karolyi, G.A., Stulz, R.M. (2004) Why are foreign firms listed in the U.S. worth more? Journal of Financial Economics 71: 205-238.

Doidge, C., Karolyi, G.A., Stulz, R.M. (2004b) Why do countries matter so much for corporate governance? Working Paper 10726. Cambridge MA, National Bureau of Economic Research.

Durnev, K., Kim, E.H. (2005) To steal or not to steal: firms attributes, legal environment, and valuation. The Journal of Finance (forthcoming).

Dyck, A., Zingales, L. (2004) Private benefits of control: An international comparison. The Journal of Finance 59: 537-600.

European Commission (2003) Progress on Financial Services: Ninth Report. Brussels 25.11.2003. http://europa.eu.int/comm/internal_market/en/finances/actionplan/.

Ferrell, A. (2003) Why continental European takeover law matters. Discussion Paper 454. Cambridge, MA: Harvard Law School.

FTSE (2004) Ground rules for the management of the FTSE Eurotop 100, FTSE Euro 100, FTSE Eurotop 300, FTSE EuroMid Indices. www.ftse.com.

Gilson, R.J., Milhaupt, C.J. (2004) Choice as regulatory reform: The case of Japanese corporate governance. www.ssrn.com. 
Gordon, J.N. (1988) Ties that bond: Dual class common stock and the problem of shareholder choice. California Law Review 76: 1-85.

Gompers, P.A., Ishii, J.L., Metrick, A. (2003) Corporate governance and equity prices. The Quarterly Journal of Economics 118: 107-155.

Healey, P.M., Palepu, K.G. (2001) Information asymmetry, corporate disclosure, and the capital markets: A review of the empirical disclosure literature. Journal of Accounting and Economics 31: 405-440.

Hebb, T., Wójcik, D. (2004) Global standards and emerging markets: the institutional investment value chain and CalPERS' investment strategy. Working Paper 04-05, School of Geography and the Environment, University of Oxford. Forthcoming in Environment and Planning A.

Hosmer, D.W., Lemeshaw, S. (2000) Applied Logistic Regression. New York: John Wiley \& Sons.

Karolyi, G.A. (2004) The world of cross-listings and cross-listings of the world: challenging the conventional wisdom. www.ssrn.com.

Khanna, T., Palepu, K.G., Srinivasan, S. (2004) Disclosure practices of foreign companies interacting with U.S. markets. Journal of Accounting Research 42: 475-508.

Klapper, L.F., Love, I. (2003) Corporate governance, investor protection, and performance in emerging markets. Journal of Corporate Finance 195: 1-26.

Lang, M., Lins, K., Miller, D. (2003) ADRs, analysts, and accuracy: does cross-listing in the U.S. improve a firm's information environment and increase market value? Journal of Accounting Research 41: 317-345.

La Porta, R., Lopez de Silanes, F., Shleifer, A., Vishny, R. (1997) Legal determinants of external finance. Journal of Finance 52: 1131-1150.

Licht, A.N. (2004) Cross-listing and corporate governance: Bonding or avoiding? Corporate Ownership and Control 1(4): 36-48.

Licht, A.N. (2001) Managerial opportunism and foreign listing: Some direct evidence. University of Pennsylvania Journal of International Economic Law 22: 325-348.

Merton, R. (1987) A simple model of capital market equilibrium with incomplete information. The Journal of Finance 42: 483-510.

Miller, D. (1999) The market reaction to international cross-listings: Evidence from depository receipts. Journal of Financial Economics 51: 103-123.

OECD (1999) Principles of Corporate Governance. Paris: OECD.

Pagano, M., Röell, A.A., Zechner, J. (2002) The geography of equity listing: Why do companies list abroad? The Journal of Finance 57 (6): 2651-2694.

Pagano, M., Randl, O., Röell, A.A., Zechner, J. (2001) What makes stock exchanges succeed? Evidence from stock listing decisions. European Economic Review 45: 770-782.

Poser, N. (2001) The stock exchanges of the United States and Europe: Automation, globalisation and consolidation. University of Pennsylvania Journal of International Economic Law 22: 497-540.

Reese, W., Weisbach, M. (2002) Protection of minority shareholder interests, cross-listing in the United States, and subsequent equity offerings. Journal of Financial Economics 66: 65-104. 
Sarkissian, S., Schill, M.J. (2004) The overseas listing decision: New evidence of proximity preference.

The Review of Financial Studies 17: 769-809.

Saudagaran, S.M., Biddle, G.C. (1995) Foreign listing location: A study of MNCs and stock exchanges in eight countries. Journal of International Business Studies 26 (2): 319-341.

Shleifer, A., Vishny, R.W. (1997) A survey of corporate governance. Journal of Financial Economics, 52: 737-783.

Siegel, J. (2003) Can foreign firms bond themselves effectively by submitting to U.S. law? Unpublished working paper. Cambridge MA: MIT.

Simonian, H. (2004) Europe's first victim of Sarbanes-Oxley? Financial Times, June 29: 14.

Stulz, R.M. (1999) Globalization of equity markets and the cost of capital. Journal of Applied Corporate

Finance 12: 8-25.

Wójcik, D. (2004) Convergence in corporate governance: Empirical evidence from Europe 2000-2003.

Unpublished working paper. Oxford: Oxford University. Available on www.ssrn.com.

At home?

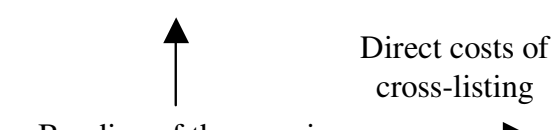

Bonding of the promise

\section{Cross-listing}

in a stricter corporate

governanance regime

Promise to improve corporate governance and not to extract private benefits

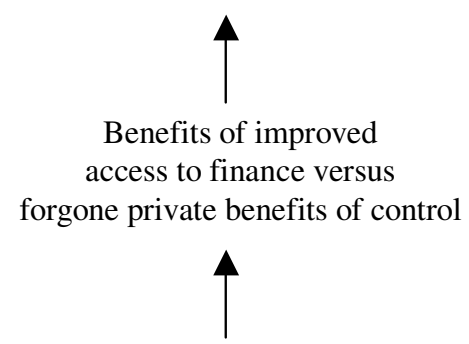

Demand for improved access to external finance to realise investment opportunities
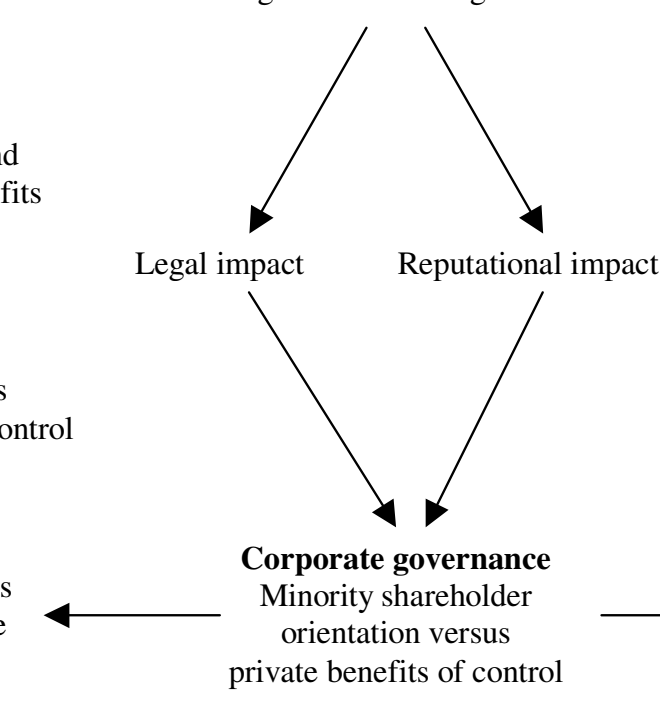

Direct costs of

cross-listing

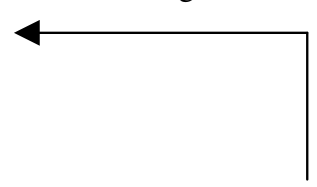

Forgone private benefits of control

Motives for cross-listing other than access to external finance e.g. visibility in export markets

Corporate governance

Minority shareholder

rivate benefits of control

Figure 1. Corporate governance and cross-listing: a conceptual framework 
Table 1. Sample companies according to their U.S. cross-listing status

\begin{tabular}{|c|c|c|c|c|c|c|c|c|c|c|c|c|c|}
\hline \multirow[t]{2}{*}{$\begin{array}{l}\text { Country of } \\
\text { incorporation }\end{array}$} & \multicolumn{3}{|c|}{$\begin{array}{c}\text { Level II or III } \\
\text { ADRs } \\
\end{array}$} & \multicolumn{4}{|c|}{$\begin{array}{c}\text { Level I or Rule 144A } \\
\text { ADRs }\end{array}$} & \multicolumn{3}{|c|}{ None U.S. CL } & \multicolumn{3}{|c|}{ Total } \\
\hline & 2000-3 & 20002 & 2003 & $2000-3$ & $2000 \mathrm{~N}$ & N/A* & 2003 & $2000-3$ & 2000 & 2003 & $2000-3$ & 2000 & 2003 \\
\hline France & 16 & 9 & 12 & 24 & 10 & 8 & 21 & 10 & 15 & 7 & 50 & 42 & 40 \\
\hline Germany & 12 & 6 & 12 & 11 & 4 & 5 & 8 & 14 & 11 & 10 & 37 & 26 & 30 \\
\hline Italy & 7 & 5 & 5 & 7 & 1 & 5 & 5 & 20 & 13 & 12 & 34 & 24 & 22 \\
\hline Netherlands & 14 & 13 & 13 & 7 & 5 & 1 & 5 & 1 & 1 & 1 & 22 & 20 & 19 \\
\hline Spain & 6 & 6 & 5 & 1 & 0 & 1 & 1 & 7 & 3 & 7 & 14 & 10 & 13 \\
\hline Sweden & 6 & 4 & 5 & 10 & 3 & 6 & 10 & 5 & 2 & 3 & 21 & 15 & 18 \\
\hline Switzerland & 8 & 4 & 8 & 7 & 6 & 1 & 7 & 6 & 5 & 3 & 21 & 16 & 18 \\
\hline United Kingdom & 54 & 32 & 44 & 39 & 16 & 14 & 28 & 21 & 14 & 13 & 114 & 76 & 85 \\
\hline Other countries & 19 & 13 & 16 & 16 & 4 & 4 & 12 & 13 & 7 & 11 & 48 & 28 & 39 \\
\hline Total & 142 & 92 & 120 & 122 & 49 & 45 & 97 & 97 & 71 & 67 & 361 & 257 & 284 \\
\hline
\end{tabular}

Note: *no data on the time of cross-listing

Source: Authors' calculations based on data from JP Morgan Chase\&Co. and Bank of New York

Table 2. Sample companies from non-financial sectors according to their European cross-listing status in 2003

\begin{tabular}{lrrrrrrr}
\hline \multicolumn{1}{c}{$\begin{array}{c}\text { Country of } \\
\text { incorporation }\end{array}$} & $\begin{array}{c}\text { Deutsche } \\
\text { Börse }\end{array}$ & $\begin{array}{c}\text { Stock } \\
\text { Exchange }\end{array}$ & $\begin{array}{c}\text { Euronext } \\
\text { Paris }\end{array}$ & $\begin{array}{c}\text { Swiss } \\
\text { Exchange }\end{array}$ & $\begin{array}{c}\text { Other } \\
\text { European }\end{array}$ & $\begin{array}{c}\text { No } \\
\text { European }\end{array}$ & $\begin{array}{c}\text { No. of } \\
\text { companies }\end{array}$ \\
\hline France & 31 & 23 & N/A & 34 & 45 & 0 & 35 \\
Germany & N/A & 19 & 7 & 20 & 41 & 3 & 24 \\
Italy & 6 & 4 & 1 & 6 & 1 & 2 & 8 \\
Netherlands & 9 & 9 & 6 & 9 & 13 & 3 & 15 \\
Spain & 7 & 6 & 4 & 7 & 3 & 3 & 10 \\
Sweden & 11 & 12 & 4 & 12 & 16 & 0 & 12 \\
Switzerland & 11 & 11 & 3 & N/A & 7 & 2 & 13 \\
United Kingdom & 49 & N/A & 12 & 52 & 7 & 15 & 67 \\
Other countries & 22 & 4 & 4 & 21 & 20 & 2 & 24 \\
Total & 146 & 88 & 41 & 161 & 153 & 30 & 208 \\
\hline
\end{tabular}

Source: Authors' calculations based on database Amadeus by Bureau van Dijk and information from individual stock exchanges 
Table 3. Corporate governance ratings in 2000 and 2003 (median values)

\begin{tabular}{|c|c|c|c|c|c|}
\hline Country & $\begin{array}{c}\text { Total } \\
\text { corporate } \\
\text { governance }\end{array}$ & $\begin{array}{l}\text { Shareholders' } \\
\text { rights\&duties }\end{array}$ & $\begin{array}{l}\text { Take-over } \\
\text { defences }\end{array}$ & Disclosure & $\begin{array}{c}\text { Board } \\
\text { structure \& } \\
\text { functioning }\end{array}$ \\
\hline \multicolumn{6}{|l|}{2003 ratings } \\
\hline France & 22.6 & $6.2 * *$ & 4 & 7.0 & $5.8 *$ \\
\hline Germany & $17.3 * * *$ & 6.5 & $1 * *$ & $6.2 * * *$ & $3.5 * * *$ \\
\hline Italy & $17.6 * * *$ & $6.0 * * *$ & $0 * * *$ & 6.6 & $5.1 * * *$ \\
\hline Netherlands & $17.6 * * *$ & $5.2 * * *$ & $1 * *$ & 6.7 & $5.0 * *$ \\
\hline Spain & $16.2 * *$ & $5.4 * *$ & $1 * *$ & $6.1 * *$ & $4.5 * *$ \\
\hline Sweden & 21.6 & 6.4 & 5 & $5.8 * * *$ & $4.4 * * *$ \\
\hline Switzerland & 19.2 & 5.7 & 1 & $5.9^{* * * *}$ & 5.5 \\
\hline United Kingdom & $30.4 * * *$ & $7.7 * * *$ & $8 * * *$ & $7.9 * * * *$ & $6.8 * * *$ \\
\hline $\begin{array}{l}\text { Total } \\
2000 \text { ratings }\end{array}$ & 21.1 & 6.5 & 2 & 6.9 & 5.6 \\
\hline France & 17.2 & 6.4 & 1 & $4.2 * * *$ & 4.5 \\
\hline Germany & 18.7 & 7.2 & 6 & $3.9 *$ & $2.9 * * *$ \\
\hline Italy & 16.1 & 7.2 & $0.5 *$ & 4.6 & $3.3 * * *$ \\
\hline Netherlands & $12.8 * * *$ & $3.9 * * *$ & $0 * * *$ & 4.7 & $3.4 * * *$ \\
\hline Spain & $13.7 * * *$ & 4.6 & $1 * * *$ & 3.6 & 4.1 \\
\hline Sweden & 19.0 & 5.1 & 6 & 3.8 & 3.6 \\
\hline Switzerland & $11.5 *$ & 5.1 & 1 & $3.0 * * *$ & $2.4 * * *$ \\
\hline United Kingdom & $27.3 * * *$ & $6.9 * * *$ & $8 * * *$ & $6.7 * * *$ & $6.1 * * *$ \\
\hline Total & 18.3 & 6.6 & 2 & 4.7 & 3.9 \\
\hline
\end{tabular}

Note: Significance at $10 \%(*), 5 \%(* *)$, and $1 \%(* * *)$ level

As the distribution of ratings is not normal or symmetric we used a nonparametric median method testing the null hypothesis that a given country or industry has the same median rating as the rest of the sample i.e. all other countries.

Source: Authors' calculations based on data provided by Deminor Rating 
Table 4. Corporate governance ratings versus the U.S. cross-listing status in 2003

\begin{tabular}{|c|c|c|c|c|c|c|c|c|c|c|}
\hline \multirow{2}{*}{$\begin{array}{l}\text { Country and the } \\
\text { U.S. cross- } \\
\text { listing status }\end{array}$} & \multicolumn{2}{|c|}{$\begin{array}{l}\text { Total corporate } \\
\text { governance }\end{array}$} & \multicolumn{2}{|c|}{$\begin{array}{l}\text { Shareholders' } \\
\text { rights\&duties }\end{array}$} & \multicolumn{2}{|c|}{$\begin{array}{l}\text { Take-over } \\
\text { defences }\end{array}$} & \multicolumn{2}{|c|}{ Disclosure } & \multicolumn{2}{|c|}{$\begin{array}{c}\text { Board structure } \\
\& \text { functioning }\end{array}$} \\
\hline & Avg & Med & Avg & Med & Avg & Med & Avg & Med & Avg & Med \\
\hline \multicolumn{11}{|l|}{ France } \\
\hline Level II or III & 23.85 & 24.71 & 5.65 & 5.90 & 4.83 & 5.00 & 7.50 & 7.61 & 5.87 & 5.94 \\
\hline Level I or 144A & 22.19 & 22.46 & 6.19 & 6.38 & 3.29 & 4.00 & 6.74 & 6.68 & 5.97 & 5.94 \\
\hline None & 19.96 & 17.50 & 6.10 & 6.02 & 2.57 & 1.00 & 6.30 & $6.41 * *$ & 4.99 & $5.05 *$ \\
\hline \multicolumn{11}{|l|}{ Germany } \\
\hline Level II or III & 19.96 & 19.29 & 6.78 & 6.84 & 2.92 & 3.00 & 6.44 & 6.38 & 3.82 & 3.75 \\
\hline Level I or $144 \mathrm{~A}$ & 17.46 & 15.43 & 5.96 & 6.09 & 2.25 & 0.50 & 5.87 & 5.91 & 3.37 & 3.19 \\
\hline None & 16.55 & $15.60 * *$ & 6.86 & 6.37 & 1.10 & $1.00 * *$ & 5.49 & 5.69 & 3.09 & 2.94 \\
\hline \multicolumn{11}{|l|}{ Italy } \\
\hline Level II or III & 19.83 & 20.84 & 5.82 & 6.04 & 0.80 & 0.00 & 7.88 & 8.48 & 5.33 & 5.26 \\
\hline Level I or 144A & 17.40 & 17.18 & 6.05 & 6.10 & 0.40 & 0.00 & 6.29 & 6.67 & 4.66 & 4.12 \\
\hline None & 17.10 & $17.18 * * *$ & 5.52 & 5.97 & 0.00 & 0.00 & 6.58 & 6.39 & 5.00 & 5.11 \\
\hline \multicolumn{11}{|l|}{ UK } \\
\hline Level II or III & 29.80 & 30.44 & 7.52 & 7.88 & 7.55 & 8.00 & 7.97 & 7.93 & 6.77 & 6.83 \\
\hline Level I or 144A & 28.80 & 30.50 & 7.39 & 7.73 & 6.93 & 8.00 & 7.75 & 7.71 & 6.73 & 6.80 \\
\hline None & 28.54 & 30.02 & 7.34 & 7.73 & 6.92 & 8.00 & 7.75 & 7.76 & 6.53 & 6.43 \\
\hline
\end{tabular}

Note: Significance at $10 \%(*), 5 \%(* *)$, and $1 \%(* * *)$ level

The significance statistics in row Level II or III refers to the difference in medians between Level II or III and Level I or 144A; in row Level I or 144A - the difference between Level I or 144A and None; in row None - the difference between Level II or III and None; for the type of test see notes to table 3 Source: Authors' calculations based on data provided by Deminor Rating

Table 5. Difference in medians around the date of cross-listings in the U.S.

\begin{tabular}{|c|c|c|c|c|c|c|}
\hline & \multicolumn{6}{|c|}{ Relative year of cross-listing } \\
\hline & -2 & -1 & 0 & 1 & 2 & $>2$ \\
\hline \multicolumn{7}{|c|}{ Firms with Level I or 144A ADRs versus those without a U.S. cross-listing } \\
\hline Total corporate governance & $4.12 * *$ & $2.58 *$ & 1.47 & $2.26 * *$ & $2.78 * * *$ & $2.86 * * *$ \\
\hline Shareholders' rights and duties & $1.20 * *$ & $0.72 *$ & 0.29 & -0.14 & 0.12 & 0.33 \\
\hline Takeover defences & $2.62 * *$ & 1.01 & 1.24 & $1.49 * *$ & $2.03 * * *$ & $1.70 * * *$ \\
\hline Disclosure & 0.16 & $0.85 * * *$ & 0.36 & $0.63 * * *$ & $0.44 *$ & $0.43 * * *$ \\
\hline Board structure and functioning & 0.14 & 0.00 & 0.18 & 0.28 & 0.19 & $0.40 * * *$ \\
\hline \multicolumn{7}{|c|}{ Firms with Level II or III ADRs versus those without a U.S. cross-listing } \\
\hline Total corporate governance & $3.99 * * *$ & $3.10 * * *$ & $3.67 * * *$ & $3.77 * * *$ & $3.86 * * *$ & $2.70 * * *$ \\
\hline Shareholders' rights and duties & 0.04 & 0.11 & -0.01 & 0.08 & 0.03 & -0.05 \\
\hline Takeover defences & $2.75 * * *$ & $1.70 * *$ & $2.27 * * *$ & $2.19 * * *$ & $2.20 * * *$ & $1.08 * *$ \\
\hline Disclosure & $0.90 * * *$ & $0.80 * * *$ & $0.72 * * *$ & $0.84 * * *$ & $0.93 * * *$ & $0.99 * * *$ \\
\hline Board structure and functioning & 0.30 & $0.49 * * *$ & $0.50 * * *$ & $0.66 * * *$ & $0.70 * * *$ & $0.69 * * *$ \\
\hline
\end{tabular}

Note: Significance at $10 \%(*), 5 \%(* *)$, and $1 \%(* * *)$ level

Source: Authors' calculations based on data provided by Deminor Rating 
Table 6. Descriptive statistics on predictor variables for multinomial logistic regression

\begin{tabular}{lcrrrrrrrrrr}
\hline & \multicolumn{4}{c}{2000} & \multicolumn{1}{c}{2003} \\
& N & Min & Max & Mean & Std. Dev. & N & Min & Max & Mean Std. Dev. \\
\hline Total corporate governance & 212 & 7.54 & 31.51 & 19.02 & 6.49 & 284 & 10.26 & 33.57 & 22.60 & 6.29 \\
Sharehold. rights and duties & 212 & 2.53 & 8.19 & 6.08 & 1.37 & 284 & 3.00 & 8.53 & 6.54 & 1.23 \\
Takeover defences & 212 & 0.00 & 10.00 & 3.83 & 3.90 & 284 & 0.00 & 10.00 & 3.96 & 3.81 \\
Disclosure & 212 & 1.00 & 7.83 & 4.80 & 1.65 & 284 & 3.03 & 9.17 & 6.74 & 1.21 \\
Board str. \& functioning & 212 & 1.55 & 7.06 & 4.28 & 1.53 & 284 & 1.46 & 7.88 & 5.35 & 1.42 \\
Foreign sales percentage & 153 & 0.00 & 100.00 & 54.87 & 29.95 & 208 & 0.00 & 100.00 & 53.69 & 28.16 \\
Asset growth rate & 189 & -80.00 & 583.00 & 28.19 & 57.37 & 272 & -32.00 & 59.00 & -0.28 & 12.55 \\
Price-to-Book Value & 183 & 0.70 & 37.97 & 4.11 & 4.21 & 264 & 0.68 & 178.76 & 3.41 & 11.10 \\
Hi-Technology dummy & 212 & 0.00 & 1.00 & 0.17 & 0.38 & 284 & 0.00 & 1.00 & 0.15 & 0.36 \\
Log of Total Asset Value & 190 & 3.04 & 5.85 & 4.37 & 0.64 & 273 & 3.06 & 5.95 & 4.36 & 0.67 \\
\hline
\end{tabular}

Note: For the definitions of corporate governance ratings see Appendix 1 for the definitions of other variables see Appendix 2

Source: Authors' calculations based on data provided by Deminor Rating and FactSet dataset 
Table 7. Logistic regression results: dependent variable - the U.S. cross-listing status

\begin{tabular}{|c|c|c|c|c|c|c|}
\hline & $\begin{array}{c}\text { Total } \\
\text { corporate } \\
\text { governance }\end{array}$ & $\begin{array}{c}\text { Shareholders' } \\
\text { rights and } \\
\text { duties }\end{array}$ & $\begin{array}{l}\text { Take-over } \\
\text { defences }\end{array}$ & Disclosure & \multicolumn{2}{|c|}{$\begin{array}{l}\text { Board structure } \\
\text { and functioning }\end{array}$} \\
\hline \multicolumn{7}{|l|}{2003} \\
\hline Number of observations & 284 & 284 & 284 & 284 & 284 & \\
\hline 2 Log Likelihood & -248.30 & 255.45 & -250.36 & -237.66 & -243.69 & \\
\hline Chi-Square & 158.73 & 151.58 & 156.67 & 169.36 & 163.33 & \\
\hline Significance & 0.00 & 0.00 & 0.00 & 0.00 & 0.00 & \\
\hline Pseudo R-Square & 0.55 & 0.53 & 0.54 & 0.57 & 0.56 & \\
\hline \multicolumn{7}{|l|}{$\%$ of correct predictions } \\
\hline Level II or III US listing & 83 & 83 & 84 & 86 & \multicolumn{2}{|l|}{85} \\
\hline Level I or 144a US-listing & 64 & 60 & 62 & 65 & \multicolumn{2}{|l|}{64} \\
\hline No US-listing & 47 & 39 & 47 & 42 & \multicolumn{2}{|l|}{56} \\
\hline Level II or III US listing & $\operatorname{Exp}(B)$ Sig. & $\operatorname{Exp}(B)$ Sig. & $\operatorname{Exp}(B)$ Sig. I & $\operatorname{Exp}(B)$ Sig. & $\operatorname{Exp}(B)$ & \\
\hline Corporate governance & 1.1830 .01 & $0.890 \quad 0.68$ & 1.1820 .06 & 4.8250 .00 & 3.722 & 0.00 \\
\hline Foreign sales percentage & 1.0600 .00 & 1.0630 .00 & 1.0620 .00 & 1.0600 .00 & 1.060 & 0.00 \\
\hline Asset growth rate & 0.9370 .05 & 0.9330 .03 & 0.9360 .04 & 0.9380 .06 & 0.938 & 0.05 \\
\hline Price-to-Book Value & 1.0370 .81 & 1.0290 .86 & 1.0410 .80 & 1.0140 .88 & 1.014 & 0.89 \\
\hline High-tech dummy & 83.9340 .00 & 111.3280 .00 & 92.1530 .00 & 109.7540 .00 & 84.974 & 0.00 \\
\hline Log of Total Asset Value & 14.2830 .00 & $16.203 \quad 0.00$ & 16.3020 .00 & 9.9250 .00 & 10.033 & 0.00 \\
\hline Level I or 144a US-listing & $\operatorname{Exp}(B)$ Sig. & $\operatorname{Exp}(B)$ Sig. & $\operatorname{Exp}(B)$ Sig. I & $\operatorname{Exp}(B)$ Sig. & $\operatorname{Exp}(B)$ & g. \\
\hline Corporate governance & 1.1450 .02 & 0.9340 .80 & 1.1950 .03 & 1.4750 .24 & 2.811 & 0.01 \\
\hline Foreign sales percentage & 1.0190 .14 & $1.020 \quad 0.11$ & 1.0190 .13 & 1.0200 .11 & 1.019 & 0.15 \\
\hline Asset growth rate & 1.0100 .73 & 1.0040 .90 & 1.0070 .80 & 1.0030 .92 & 1.016 & 0.58 \\
\hline Price-to-Book Value & 0.9060 .49 & 0.9110 .54 & 0.9180 .55 & 0.9020 .45 & 0.891 & 0.41 \\
\hline High-tech dummy & 4.1170 .27 & $\begin{array}{lll}5.551 & 0.18\end{array}$ & 4.5490 .24 & 5.3030 .20 & 3.940 & 0.29 \\
\hline Log of Total Asset Value & 2.1560 .20 & $2.409 \quad 0.12$ & 2.4200 .13 & 2.3030 .16 & 1.660 & 0.40 \\
\hline \multicolumn{7}{|l|}{2000} \\
\hline Number of observations & 212 & 212 & 212 & 212 & \multicolumn{2}{|l|}{212} \\
\hline 2 Log Likelihood & -189.46 & -187.82 & -189.49 & -176.45 & \multicolumn{2}{|l|}{-188.76} \\
\hline Chi-Square & 116.03 & 117.67 & 116.01 & 129.05 & \multicolumn{2}{|l|}{116.74} \\
\hline Significance & 0.00 & 0.00 & 0.00 & 0.00 & \multicolumn{2}{|l|}{0.00} \\
\hline $\begin{array}{l}\text { Pseudo R-Square } \\
\% \text { of correct predictions }\end{array}$ & 0.55 & 0.55 & 0.55 & 0.58 & \multicolumn{2}{|l|}{0.55} \\
\hline Level II or III US listing & 81 & 80 & 80 & 86 & \multicolumn{2}{|l|}{82} \\
\hline Level I or 144a US-listing & 52 & 52 & 58 & 49 & \multicolumn{2}{|l|}{42} \\
\hline No US-listing & 63 & 66 & 66 & 76 & \multicolumn{2}{|l|}{70} \\
\hline Level II or III US listing & \multicolumn{6}{|c|}{$\operatorname{Exp}(B)$ Sig. $\operatorname{Exp}(B)$ Sig. $\operatorname{Exp}(B)$ Sig. $\operatorname{Exp}(B)$ Sig. $\operatorname{Exp}(B)$ Sig. } \\
\hline Corporate governance & 1.0500 .45 & 0.7860 .35 & 1.0160 .85 & 5.4370 .00 & 1.947 & 0.09 \\
\hline Foreign sales percentage & 1.0490 .00 & 1.0510 .00 & 1.0500 .00 & 1.0510 .00 & 1.050 & 0.00 \\
\hline Asset growth rate & 0.9960 .70 & 0.9970 .77 & 0.9970 .71 & 0.9930 .43 & 1.000 & 1.00 \\
\hline Price-to-Book Value & 1.1080 .15 & 1.1010 .19 & 1.1020 .18 & 1.1320 .10 & 1.100 & 0.19 \\
\hline High-tech dummy & 14.8000 .00 & 15.1520 .00 & 14.6060 .00 & 18.3810 .00 & 16.055 & 0.00 \\
\hline Log of Total Asset Value & 19.7450 .00 & $20.044 \quad 0.00$ & 21.1320 .00 & 15.9950 .00 & 17.300 & 0.00 \\
\hline Level I or $144 \mathrm{a}$ US-listing & \multicolumn{6}{|c|}{$\operatorname{Exp}(B)$ Sig. $\operatorname{Exp}(B)$} \\
\hline Corporate governance & 1.1140 .10 & 1.2760 .37 & 1.1350 .14 & 1.9160 .12 & 1.018 & 0.96 \\
\hline Foreign sales percentage & 1.0310 .03 & 1.0320 .02 & 1.0310 .02 & 1.0350 .01 & 1.034 & 0.01 \\
\hline Asset growth rate & 0.9790 .10 & 0.9810 .15 & 0.9780 .09 & 0.9740 .06 & 0.981 & 0.14 \\
\hline Price-to-Book Value & 1.0190 .85 & 0.9770 .83 & 1.0200 .85 & 0.9990 .99 & 0.985 & 0.89 \\
\hline High-tech dummy & 1.4240 .75 & $\begin{array}{ll}1.271 & 0.83\end{array}$ & 1.4140 .75 & 1.4800 .73 & 1.672 & 0.63 \\
\hline Log of Total Asset Value & 3.3990 .10 & $3.545 \quad 0.08$ & 3.7490 .07 & 3.3910 .10 & 3.734 & 0.07 \\
\hline
\end{tabular}

Note: Country dummies included but not reported; Cox-Snell pseudo R-squares reported Source: Authors' calculations based on data provided by Deminor Rating and FactSet database 
Table 8. Country-adjusted corporate governance ratings according to European and the U.S. cross-listing

\begin{tabular}{|c|c|c|c|c|c|c|}
\hline \multirow[b]{2}{*}{ Cross-listing on: } & \multicolumn{2}{|c|}{ Type of U.S. cross-listing > } & \multicolumn{2}{|c|}{ Level II or III ADRs } & \multicolumn{2}{|c|}{ Level I, Rule 144A or None } \\
\hline & CG category & Cross-listed? & $\mathrm{N}$ & Median Sig. & $\mathrm{N}$ & Median \\
\hline \multirow[t]{10}{*}{ Deutsche Börse } & \multirow[t]{2}{*}{ Total C.G. } & Yes & 76 & 4 & 70 & 0.5 \\
\hline & & No & 12 & 7 & 26 & 1 \\
\hline & \multirow[t]{2}{*}{ Share.R.\&D. } & Yes & 76 & 2 & 70 & 2 \\
\hline & & No & 12 & 4 & 26 & 6 \\
\hline & \multirow[t]{2}{*}{ Takeover D. } & Yes & 76 & 14 & 70 & -9 \\
\hline & & No & 12 & 28.5 & 26 & 2.5 \\
\hline & \multirow{2}{*}{ Disclosure } & Yes & 76 & 4 & 70 & -2.5 \\
\hline & & No & 12 & 0.5 & 26 & -3 \\
\hline & \multirow[t]{2}{*}{ Board S.\&F. } & Yes & 76 & 4 & 70 & -1 \\
\hline & & No & 12 & 3 & 26 & -4 \\
\hline \multirow{10}{*}{$\begin{array}{l}\text { London Stock } \\
\text { Exchange }\end{array}$} & \multirow[t]{2}{*}{ Total C.G. } & Yes & 43 & 3 & 45 & -9 \\
\hline & & No & 20 & -0.5 & 33 & -5 \\
\hline & \multirow[t]{2}{*}{ Share.R.\&D. } & Yes & 43 & -3 & 45 & -2 \\
\hline & & No & 20 & -1 & 33 & 6 \\
\hline & \multirow[t]{2}{*}{ Takeover D. } & Yes & 43 & -14 & 45 & -57 \\
\hline & & No & 20 & 0 & 33 & -100 \\
\hline & \multirow{2}{*}{ Disclosure } & Yes & 43 & 8 & 45 & 0 \\
\hline & & No & 20 & 5.5 & 33 & -7 \\
\hline & \multirow[t]{2}{*}{ Board S.\&F. } & Yes & 43 & 8 & 45 & -1 \\
\hline & & No & 20 & 2 & 33 & -5 \\
\hline \multirow[t]{10}{*}{ Euronext Paris } & \multirow[t]{2}{*}{ Total C.G. } & Yes & 30 & 5.5 & 11 & 1 \\
\hline & & No & 57 & 3 & 75 & -1 \\
\hline & \multirow[t]{2}{*}{ Share.R.\&D. } & Yes & 30 & 0.5 & 11 & -4 \\
\hline & & No & 57 & 3 & 75 & 2 \\
\hline & \multirow[t]{2}{*}{ Takeover D. } & Yes & 30 & 14 & 11 & 0 \\
\hline & & No & 57 & 14 & 75 & -50 \\
\hline & Disclosure & Yes & 30 & 3.5 & 11 & $3 *$ \\
\hline & & No & 57 & 3 & 75 & -3 \\
\hline & Board S.\&F. & Yes & 30 & 5.5 & 11 & 0 \\
\hline & & No & 57 & 4 & 75 & -4 \\
\hline Swiss Exchange & Total C.G. & Yes & 80 & 4 & 81 & -1 \\
\hline & & No & 12 & 7 & 22 & 1 \\
\hline & Share.R.\&D. & Yes & 80 & 2 & 81 & $2 * *$ \\
\hline & & No & 12 & 4 & 22 & 6 \\
\hline & Takeover D. & Yes & 80 & 14 & 81 & -43 \\
\hline & & No & 12 & 28.5 & 22 & -11.5 \\
\hline & Disclosure & Yes & 80 & 4 & 81 & -3 \\
\hline & & No & 12 & 0.5 & 22 & -2 \\
\hline & Board S.\&F. & Yes & 80 & 4 & 81 & -3 \\
\hline & & No & 12 & 3 & 22 & -1 \\
\hline Any European & Total C.G. & Yes & 88 & 4 & 90 & -2 \\
\hline exchange & & No & 10 & 7 & 20 & 1 \\
\hline & Share.R.\&D. & Yes & 88 & 2 & 90 & $1.5^{* *}$ \\
\hline & & No & 10 & 1.5 & 20 & 6 \\
\hline & Takeover D. & Yes & 88 & 14 & 90 & -50 \\
\hline & & No & 10 & 28.5 & 20 & 2.5 \\
\hline & Disclosure & Yes & 88 & 4 & 90 & -2 \\
\hline & & No & 10 & 2 & 20 & -3 \\
\hline & Board S.\&F. & Yes & 88 & 4 & 90 & -2.5 \\
\hline & & No & 10 & 3 & 20 & -3 \\
\hline
\end{tabular}

Source: Authors' based on data from Deminor Rating, Amadeus, and individual stock exchanges 


\section{Appendix 1}

Major criteria considered within the Deminor corporate governance rating categories (based on Deminor, 2003)

\section{Shareholders' rights and duties}

The major criterion concerns the respect of the one-share one-vote one-dividend principle, the violation of which implies that some shareholders are privileged over others. It is also important whether there are procedures in place to make voting easy for shareholders. Other criteria include shareholders' rights to propose items to be considered at the Annual General Meeting, attendance rates at the Annual General Meetings and whether existing shareholders maintain pre-emptive rights.

\section{Take-over defences}

Involves the presence and the strength of devices that could be used to protect the company from a hostile take-over. Some of them result from the ownership structure. A majority shareholder for example makes a take-over impossible unless it is agreed with them, irrespective of the interests of minority shareholders. Other devices making a take-over impossible or unattractive to a hostile-bidder include management or board members making themselves impossible to dismiss (board and management insulation) or dismissible only after a hefty payment (golden parachutes).

\section{Disclosure}

Analyses the transparency of a corporation measured by the quantity and quality of non-financial information on its governance structure, including the shareholder structure, the composition and functioning of the board, availability of documents in English, accounting standards, and environmental information. Other criteria include information on executive and board remuneration, stock options, as well as the rotation and fees of auditors.

\section{Board structure and functioning}

The major factor refers to the composition of the board. The board should include members who are independent from both the company management and major shareholders. Board members should be experienced and have a diverse background, and the same person should not take the positions of the chairman of the board and the chief executive officer. Board members should meet frequently and their work should be well organised. Other criteria consider the election and the remuneration of the board. 


\section{Appendix 2}

Details of corporate characteristics used as control variables in multinomial logistic regression (if not stated otherwise based on data from FactSet)

Foreign sales percentage

Asset growth rate

Price-to-Book Value

High Technology dummy

Log of Total Asset Value
Percentage of foreign sales and revenues in total sales and revenues in 2000 and 2003 respectively

The percentage change in the year-end total balance sheet value of assets between the year of 2000 and 1999; and 2003 and 2002 respectively

Ratio obtained by dividing the year-end unit price of common shares by the unit book value of common shares for 2000 and 2003 respectively

1 if a company is classified in one of the following industries according to FTSE Dow Jones Industry Classification Benchmark: health care, telecommunications, technology

Logarithm with the base of 10 of the year-end total balance sheet value of assets for 2000 and 2003 respectively 